\section{The impact of the interpregnancy interval on birth weight and other pregnancy outcomes}

\section{O impacto do intervalo entre gestações no peso de recém-nascidos e outros desfechos da gravidez}

Abdulbari Bener 1

Najah Mohammed Saleh 2

Khalil Mohd Khalil Salameh 3

Basma Basha 4

Sharen Joseph 5

Nancy Samson 6

Rama AlBuz 7

1,6 Department of Medical Statistics and Epidemiology. Hamad Medical Corporation. Department of Public Health. Weill Cornell Medical College. PO Box 3050. Doha, State of Qatar.

E-mail:abb2007@qatar-med.cornell.edu

2 Department of Obstetrics and Gynaecology. Women's Hospital. Hamad Medical Corporation. Doha, State of Qatar.

3 NICU Unit. Women's Hospital. Hamad Medical Corporation. Doha, State of Qatar.

4,5,7 Deptartmant of Public Health and Medical Education. Weill Cornell Medical College. Doha, State of Qatar.

\section{Resumo}

Objetivos: investigar a relação entre o intervalo

Objectives: to investigate the relationship between the interpregnancy interval and low birth weight and other pregnancy outcomes.

Methods: this case-control study was carried out in hospitals from January 2010 to April 2011. For cases, mothers of 1216 newborns with birth weight $<2500 \mathrm{~g}$ were approached and 854 mothers participated (70.2\%). For controls, mothers of 1158 newborns with $\geq 2500 \mathrm{~g}$ were approached and 854 mothers participated in this study (73.7\%). Face-toface interviews were conducted to complete the questionnaires

Results: of the newborn babies with low birth weight, the risk was higher among mothers with a short interpregnancy interval (40.3\%), whereas for infants with normal birth weight, the majority of the mothers had a longer interpregnancy interval of 24 months (44.7\%). A short interpregnancy interval of 612 months was more common among women of $<25$ years $(49.4 \% ; p<0.001)$ and those who were illiterate (13.1\%; $p=0.043)$ with a higher risk of low birth weight compared to the controls. Prenatal care during the 1st trimester was lower in women with low birth weight children $(p<0.001)$. Normal delivery was observed less in women with a short birth interval among cases (58.7\%) compared to controls (79\%) $(p=0.001) . A J$-shaped association was observed between low birth weight and the interpregnancy interval.

Conclusions: a short interpregnancy interval is associated with an increased risk of low birth weight, especially in younger and illiterate women.

Key words Pregnancy, Infant, low birth weight, Risk factors entre gestações e o baixo peso de recém-nascidos e outras conseqüencias da gestação.

Métodos: este estudo caso-controle foi realizado em hospitais entre janeiro de 2010 e abril de 2011. Dentre as mães dos 1216 recém-nascidos com peso $<2500 \mathrm{~g}, 854$ (70,2\%) aceitaram participar do estudo de caso. No grupo controle, dentre as mães dos 1158 recém-nascidos com peso $\geq 2500 \mathrm{~g}$, participaram 854 $(73,7 \%)$. Para completar os questionários, foram conduzidas entrevistas face a face.

Resultados: dos recém-nascidos com baixo peso, o fator de risco foi mais alto entre as mães com curto intervalo intergestacional (40,3\%), enquanto para recém-nascidos com peso normal a maioria das mães tinham uma boa margem de intervalo intergestacional de 24 meses $(44,7 \%)$. Curtos intervalo intergestacional (6 a 12 meses) foi mais comum entre mulheres de $<25$ anos (49,4\%; $p<0,001)$ e analfabetas $(13,1 \%$; $p=0,043)$, com mais alto risco de baixo peso quando comparado aos controle. Cuidados pre-natais durante o primeiro trimestre foi menor nas mulheres com crianças de baixo peso $(p<0,001)$. Menos partos normais foi observado em mulheres com curtos intervalos de nascimento para os casos $(58,7 \%)$ comparados aos controles (79\%) ( $p=0,001)$. Uma associação não monotônica tipo função $J$, foi observada entre o baixo peso e intervalo intergestacional.

Conclusões: um curto intervalo entre gestações é associado a um risco maior de nascerem bebês de baixo peso, principalmente entre mulheres mais jovens e analfabetas.

Palavras-chave Gravidez, Recém nascido de baixo peso, Fatores de risco 


\section{Introduction}

Birth spacing has become a major health promotion program strategy for mothers and children in recent decades in developing countries. The interpregnancy interval (IPI) has been reported to influence the outcome of pregnancy and birth. The relationship between the interpregnancy interval and perinatal health is receiving increasing attention. Perinatal mortality is an indicator of poor obstetric care. About 4 million out of 130 million infants born worldwide die during the $1^{\text {st }}$ four weeks of life and more than three million are still born. ${ }^{1}$ It has been estimated that, worldwide, more than 76 million perinatal deaths occur annually, of which $98 \%$ take place in developing countries. 2 Pregnancy risk factors are all the aspects that endanger the life of the mother and the baby. The major negative pregnancy outcomes include neonatal mortality, low birth weight, still birth, malformations of the baby, and death of the mother due to difficulties during delivery. These factors may include poor nutrition of the women, child spacing, maternal age less than 15 years and over 35 years, inadequate prenatal care, lifestyle behaviours like smoking, overweight and obesity. 3 Appropriate pregnancy spacing has been recommended to achieve better perinatal outcomes. Birth spacing is thus an important consideration when planning a family.

Both short and long intervals between pregnancies have been associated with increased risk of a number of adverse perinatal outcomes, such as preterm birth, low birth weight, small size for gestational age, and perinatal death. ${ }^{4}$ Some researchers have argued that short intervals between pregnancies merely identify women already at higher reproductive risk, either because of underlying disorders, socioeconomic status or life style factors. ${ }^{5}$ It has been claimed that women with closely spaced births have insufficient time to restore the nutritional reserves needed to support fetal growth and development in the subsequent pregnancy. ${ }^{4}$ Women who become pregnant soon after completing a pregnancy are considered to be at high risk for the delivery of a low birth weight infant.

Low birth weight (LBW) remains a public health problem in many parts of the world and is associated with a range of health problems, lasting disabilities and even death. Low birth weight has considerable short- and long-term consequences and leads to high costs for individuals and societies in a developed economy. The birth weight of an infant is the single most important determinant of newborn survival, since neonatal illness in general is closely related to low birth weight. More than 20 million infants worldwide are born with low birth weight (15.5\%). ${ }^{6}$ Some epidemiological studies 6 have observed that infants born under-weight are approximately 20 times more likely to die than heavier babies. Most of the previous studies ${ }^{7-9}$ have focused on the effect of interpregnancy intervals and found that a short interpregnancy interval was associated with an increased risk of low birth weight in the infant.

In the State of Qatar, the average total fertility rate of women of child-bearing age is three children. The use of modern family planning methods is not widespread among Qatari women, which can lead to short birth intervals that affect the health of the mother and child. The vital statistics 10 reveal that a perinatal death rate in the range of 10.6 to 9.2 and low birth weight less than $2500 \mathrm{~g}(8 \%)$ have remained stable in recent years. However, as yet, no study has been conducted in the State of Qatar regarding the association between the interpregnancy interval and low birth weight. To the best of our knowledge, this is the first study investigating the impact of the interpregnancy interval on low birth weight and other adverse pregnancy outcomes.

\section{Methods}

This is a matched case-control study which was designed to determine the relationship between interpregnancy interval and low birth weight and other adverse pregnancy outcomes among Arab women in Qatar. The survey was conducted over the period from January 2010 to April 2011. Since nearly all births occur in two main government hospitals in Qatar, the Women's hospital and the Al-Khor hospital, the infants recruited from the obstetric units of these two hospitals are representative of the neonate population in Qatar. The present study is based on 854 new born babies with birth weight $<2500 \mathrm{~g}$ as cases and 854 babies with birth weight $\geq 2500 \mathrm{~g}$ as controls. The study was approved by the Research Ethics Committee of the Hamad Medical Corporation and the Institutional Review Board of the Weill Cornell Medical College, Qatar.

For cases, mothers of 1216 babies with birth weight $<2500 \mathrm{~g}$ were approached and 854 mothers consented to take part in the study, with a response rate of $70.2 \%$. The cases were recruited by simple random sampling from the postnatal wards of the Women's and Al-Khor hospitals. The birth weight of the newborns was measured immediately after delivery.

Control subjects were healthy newborns with birth weight $\geq 2500$ g. Mothers of 1158 newborns 
with birth weight $\geq 2500 \mathrm{~g}$ were identified from the postnatal wards of the Women's and Al-Khor hospitals and 854 of them agreed to participate in this study, giving a response rate of $73.7 \%$. The healthy subjects were selected in such a way as to match the age, gender and ethnicity of cases so as to provide a good representative sample of the studied population.

The primary outcome variables for the present study were low birth weight, interpregnancy interval, parity, maternal height and weight and pregnancy outcome. Low birth weight is defined as when a baby weighs less than $2500 \mathrm{~g}$ at the time of his/her birth. Normal babies are considered to be those born weighing $2500 \mathrm{~g}$ or more. The interpregnancy interval was calculated as the number of months between the date of delivery and the date of the preceding birth, minus the duration of the pregnancy. The interval was calculated in months. Interpregnancy intervals were categorized as 6-12 months, 13-23 months and 24-84 months. Maternal age was defined as completed years at time of delivery. Parity was defined as the number of previous births including still births. Maternal height and weight before pregnancy were recorded in their patient files during their first antenatal visit in $\mathrm{cm}$ and $\mathrm{kg}$ respectively. Height and weight were measured using standardized methods and all the participants wore light clothes and no shoes for this part of the examination. The body mass index (BMI) was calculated as the weight in kilograms (with $1 \mathrm{~kg}$ subtracted to allow for clothing) divided by height in meters squared. The prepregnancy BMI was categorized into four groups: underweight (BMI <20 $\left.\mathrm{kg} / \mathrm{m}^{2}\right)$, normal $\left(20-24.99 \mathrm{~kg} / \mathrm{m}^{2}\right)$, overweight (25 $\left.-29.99 \mathrm{~kg} / \mathrm{m}^{2}\right)$ and obese $\left(\geq 30 \mathrm{~kg} / \mathrm{m}^{2}\right)$.

The questionnaire was designed to meet the objective of this study. The survey was based on standardized interviews conducted by trained health professionals. The participants were interviewed by health professionals and completed the questionnaires. The questionnaire had three parts. The first included socio-demographic information such as age, gender, nationality, educational level, occupation, place of residence (urban and semi-urban), type of house, monthly income, the second part dealt with maternal characteristics and the third neonatal outcome.

A translated Arabic version of the questionnaire was revised by a bilingual consultant. The survey instrument was then tested on 50 randomly selected mothers of neonates with birth weight $<2500 \mathrm{~g}$ and 50 mothers of neonates with birth weight $>2500 \mathrm{~g}$ from the hospitals as a pilot study. The investigators made the necessary corrections and modifications after considering the minor differences and discrepancies found during the pilot study.

The statistical analysis was performed by using the Statistical Package for Social Sciences [SPSS]. Student's t test was used to ascertain the significance of differences between mean values of two continuous variables and confirmed by a non-parametric Mann-Whitney test. Chi-square analysis was performed to test for differences in proportions of categorical variables between two or more groups. For $2 \times 2$ tables, Fisher's exact test (two-tailed) replaced the chi-square test if the assumptions underlying chi-square were violated, i.e. in cases of small sample size and where the expected frequency was less than 5 in any of the cells. The level $p<0.05$ was considered as the cut-off value for significance.

\section{Results}

Table 1 shows the socio-demographic characteristics of the studied cases and controls according to interpregnancy interval. Of the newborn babies with low birth weight $<2500 \mathrm{~g}$, the risk was higher among mothers who had short interpregnancy interval of less than 6-12 months (40.3\%), whereas for normal weight newborns the majority of the mothers had a longer interpregnancy interval of 2 years or more $(44.7 \%)$. In cases of low birth weight babies, mothers with a birth interval of $13-23$ months had the lowest risk of low birth weight (24.6\%). Compared to controls, a short IPI of one year was significantly more common among younger women $(<25$ years) with low birth weight children $(21.7 \%$ vs $49.4 \%)$ and less educated mothers; illiterate $(9.1 \%$ $v s 13.1 \%)$, or with primary education only $(7.7 \% v s$ $14.2 \%)$.

Table 2 shows the distribution of selected maternal characteristics among the cases and controls according to interpregnancy interval. For cases, women of short birth interval (6-12 months) were more likely to be underweight $(8.1 \%)$ than mothers with normal weight children (4.5\%). Prenatal care during the 1 st trimester was lower in women with low birth weight children; especially those with a short birth interval who did not even attend antenatal clinics (70.9\%). Chronic hypertension was the main pregnancy complication observed among the women with low birth weight children, followed by preeclampsia and antepartum haemorrhage and pregnancy complications were found less in women with normal weight children.

Table 3 examines the neonatal outcome of mothers of low birth weight and normal weight chil- 
dren according to interpregnancy interval. Normal delivery was observed to be less common among mothers of newborns weighing less than $2500 \mathrm{~g}$ with a short IPI (58.7\%) compared to the controls (79\%). Multiple births occurred among mothers of low birth weight children especially in mothers with a prolonged interval of 2 years or more $(10 \%)$, whereas the proportion was low in cases of normal birth weight children (2.6\%).
Figure 1 shows the relationship between interpregnancy interval and low birth weight. A J-shaped association was found between the interpregnancy interval and low birth weight. Low birth weight rate was most common when the interpregnancy interval was 6 months $(25.2 \%)$, decreased as the interval increased, and was lowest when the interval was 24 months (5\%). As the interval increased, LBW slowly increased in a linear fashion.

Table 1

Socio-demographics characteristics of the studied cases and control according to interpregnancy interval $(\mathrm{N}=1708)$.

\begin{tabular}{|c|c|c|c|c|c|c|c|c|c|c|c|c|c|c|}
\hline \multirow{3}{*}{ Variables } & \multicolumn{6}{|c|}{$\begin{array}{c}\text { Cases }(<2500 \mathrm{~g}) \\
\mathrm{N}=854\end{array}$} & \multicolumn{7}{|c|}{$\begin{array}{c}\text { Control }(\geq 2500 \mathrm{~g}) \\
\mathrm{N}=\mathbf{8 5 4}\end{array}$} & \multirow{3}{*}{$p$} \\
\hline & \multicolumn{2}{|c|}{$\begin{array}{c}6-12 \\
\text { months } \\
(\mathrm{N}=344)\end{array}$} & \multicolumn{2}{|c|}{$\begin{array}{l}13-23 \\
\text { months } \\
(\mathrm{N}=210)\end{array}$} & \multicolumn{2}{|c|}{$\begin{array}{c}24-84 \\
\text { months } \\
(\mathrm{N}=300)\end{array}$} & \multirow[t]{2}{*}{$p$} & \multicolumn{2}{|c|}{$\begin{array}{c}6-12 \\
\text { months } \\
(\mathrm{N}=286)\end{array}$} & \multicolumn{2}{|c|}{$\begin{array}{c}13-23 \\
\text { months } \\
(\mathrm{N}=186)\end{array}$} & \multicolumn{2}{|c|}{$\begin{array}{c}24-84 \\
\text { months } \\
(\mathrm{N}=382)\end{array}$} & \\
\hline & $\mathrm{n}$ & $\%$ & $\mathrm{n}$ & $\%$ & $\mathrm{n}$ & $\%$ & & $\mathrm{n}$ & $\%$ & $\mathrm{n}$ & $\%$ & $\mathrm{n}$ & $\%$ & \\
\hline Age (years) & & & & & & & $<0.001$ & & & & & & & 0.239 \\
\hline$\leq 25$ & 170 & 49.4 & 53 & 25.2 & 73 & 24.3 & & 62 & 21.7 & 32 & 17.2 & 71 & 18.6 & \\
\hline $25-34$ & 80 & 23.3 & 78 & 37.1 & 111 & 37.0 & & 165 & 57.7 & 111 & 59.1 & 206 & 53.6 & \\
\hline$\geq 35$ & 94 & 27.3 & 79 & 37.6 & 116 & 38.7 & & 59 & 20.6 & 43 & 23.2 & 105 & 27.5 & \\
\hline Nationality & & & & & & & 0.292 & & & & & & & 0.534 \\
\hline Qatari & 152 & 44.2 & 100 & 47.6 & 122 & 40.7 & & 132 & 46.2 & 91 & 48.9 & 193 & 50.5 & \\
\hline Other Arab & 192 & 55.8 & 110 & 52.4 & 178 & 59.3 & & 154 & 53.8 & 95 & 51.1 & 189 & 49.5 & \\
\hline Education level & & & & & & & 0.043 & & & & & & & 0.756 \\
\hline Illiterate & 45 & 13.1 & 13 & 6.2 & 27 & 9.0 & & 26 & 9.1 & 13 & 7.0 & 26 & 6.8 & \\
\hline Primary & 49 & 14.2 & 24 & 11.4 & 49 & 16.3 & & 22 & 7.7 & 12 & 6.5 & 32 & 8.4 & \\
\hline Intermediate & 59 & 17.2 & 41 & 19.5 & 45 & 15.0 & & 35 & 12.2 & 17 & 9.1 & 46 & 12.0 & \\
\hline Secondary & 94 & 27.3 & 50 & 23.8 & 84 & 28.0 & & 105 & 36.7 & 67 & 36.0 & 130 & 34.0 & \\
\hline University & 97 & 28.2 & 82 & 39.0 & 95 & 31.7 & & 98 & 34.3 & 77 & 41.4 & 148 & 38.7 & \\
\hline Mother's occupation & & & & & & & 0.018 & & & & & & & 0.457 \\
\hline House wife & 200 & 58.1 & 107 & 51.0 & 190 & 63.3 & & 167 & 58.4 & 98 & 52.7 & 227 & 59.4 & \\
\hline Teacher & 76 & 22.1 & 63 & 30.0 & 47 & 15.7 & & 81 & 28.3 & 61 & 32.8 & 103 & 27.0 & \\
\hline Professional & 27 & 7.8 & 18 & 8.6 & 27 & 9.0 & & 23 & 8.0 & 13 & 7.0 & 38 & 9.9 & \\
\hline Business & 32 & 9.3 & 14 & 6.7 & 22 & 7.3 & & 10 & 3.5 & 9 & 4.8 & 9 & 2.4 & \\
\hline Army/police & 9 & 2.6 & 8 & 3.8 & 14 & 4.7 & & 5 & 1.7 & 5 & 2.7 & 5 & 1.3 & \\
\hline Family income (Qrs.) & & & & & & & 0.049 & & & & & & & 0.570 \\
\hline$<5000$ & 36 & 10.5 & 13 & 6.2 & 27 & 9.0 & & 19 & 6.6 & 14 & 7.5 & 29 & 7.6 & \\
\hline $5000-9,999$ & 109 & 31.7 & 74 & 35.2 & 80 & 26.7 & & 106 & 37.1 & 52 & 28.0 & 127 & 44.6 & \\
\hline $1000-14,999$ & 80 & 23.3 & 42 & 20.0 & 81 & 27.0 & & 63 & 22.0 & 47 & 25.3 & 77 & 20.2 & \\
\hline $15,000-19,999$ & 70 & 20.3 & 37 & 17.6 & 71 & 23.7 & & 76 & 26.6 & 54 & 29.0 & 107 & 28.0 & \\
\hline$>25000$ & 49 & 36.6 & 44 & 21.0 & 41 & 13.7 & & 22 & 26.5 & 19 & 10.2 & 42 & 11.0 & \\
\hline Type of residence & & & & & & & 0.196 & & & & & & & 0.893 \\
\hline Villa & 216 & 62.8 & 143() & 68.1 & 193 & 64.3 & & 181 & 63.3 & 123 & 66.1 & 239 & 62.6 & \\
\hline Flat & 102 & 29.7 & 44 & 21.0 & 79 & 26.3 & & 86 & 30.1 & 49 & 26.3 & 115 & 46.0 & \\
\hline Popular house & 26 & 7.6 & 23 & 11.0 & 28 & 9.3 & & 19 & 6.6 & 14 & 7.5 & 28 & 7.3 & \\
\hline Place of living & & & & & & & 0.184 & & & & & & & 0.362 \\
\hline Urban & 288 & 83.7 & 187 & 25.7 & 252 & 84.0 & & 240 & 83.9 & 147 & 79.0 & 308 & 80.6 & \\
\hline Semi-urban & 56 & 16.3 & 23 & 11.0 & 48 & 16.0 & & 46 & 16.1 & 39 & 21.0 & 74 & 19.4 & \\
\hline
\end{tabular}

Two sided $p$ values based on Pearson's chi square test \& fisher's exact test where the cell count was less than 5. 
Distribution of selected maternal characteristics among the cases and control according to interpregnancy interval ( $\mathrm{N}=1708)$.

\begin{tabular}{|c|c|c|c|c|c|c|c|c|c|c|c|c|c|c|}
\hline \multirow{3}{*}{ Variables } & \multicolumn{6}{|c|}{$\begin{array}{c}\text { Cases }(<2500 \mathrm{~g}) \\
\mathrm{N}=854\end{array}$} & \multicolumn{7}{|c|}{$\begin{array}{c}\text { Control }(\geq 2500 \mathrm{~g}) \\
\qquad \mathrm{N}=\mathbf{8 5 4}\end{array}$} & \multirow{3}{*}{$p$} \\
\hline & \multicolumn{2}{|c|}{$\begin{array}{c}6-12 \\
\text { months } \\
(\mathrm{N}=344)\end{array}$} & \multicolumn{2}{|c|}{$\begin{array}{c}13-23 \\
\text { months } \\
(\mathrm{N}=210)\end{array}$} & \multicolumn{2}{|c|}{$\begin{array}{c}24-84 \\
\text { months } \\
(\mathrm{N}=300)\end{array}$} & \multirow[t]{2}{*}{$p$} & \multicolumn{2}{|c|}{$\begin{array}{c}6-12 \\
\text { months } \\
(\mathrm{N}=286)\end{array}$} & \multicolumn{2}{|c|}{$\begin{array}{c}13-23 \\
\text { months } \\
(\mathrm{N}=186)\end{array}$} & \multicolumn{2}{|c|}{$\begin{array}{c}24-84 \\
\text { months } \\
(\mathrm{N}=382)\end{array}$} & \\
\hline & $\mathrm{n}$ & $\%$ & $\mathrm{n}$ & $\%$ & $\mathrm{n}$ & $\%$ & & $\mathrm{n}$ & $\%$ & $\mathrm{n}$ & $\%$ & $\mathrm{n}$ & $\%$ & \\
\hline Body mass index & & & & & & & 0.013 & & & & & & & 0.586 \\
\hline Underweight $\left(\leq 20 \mathrm{~kg} / \mathrm{m}^{2}\right)$ & 28 & 8.1 & 9 & 4.3 & 9 & 3.0 & & 13 & 4.5 & 10 & 5.4 & 17 & 4.5 & \\
\hline Normal $\left(20-24.9 \mathrm{~kg} / \mathrm{m}^{2}\right)$ & 138 & 44.4 & 68 & 32.4 & 105 & 35.0 & & 112 & 39.2 & 73 & 39.2 & 145 & 38.0 & \\
\hline Overweight $\left(25-29.9 \mathrm{~kg} / \mathrm{m}^{2}\right)$ & 103 & 29.9 & 85 & 40.5 & 113 & 37.7 & & 105 & 36.7 & 72 & 38.7 & 129 & 33.8 & \\
\hline Obese $\left(\geq 30 \mathrm{~kg} / \mathrm{m}^{2}\right)$ & 75 & 21.8 & 48 & 22.9 & 73 & 24.3 & & 56 & 19.6 & 31 & 16.7 & 91 & 23.8 & \\
\hline Parity group & & & & & & & $<0.001$ & & & & & & & 0.308 \\
\hline$<2$ & 133 & 38.7 & 37 & 17.6 & 101 & 33.7 & & 98 & 34.3 & 57 & 30.6 & 115 & 30.1 & \\
\hline $2-4$ & 135 & 39.2 & 82 & 39.0 & 129 & 43.0 & & 113 & 39.5 & 75 & 40.3 & 136 & 35.6 & \\
\hline $5-6$ & 66 & 19.2 & 53 & 25.2 & 48 & 16.0 & & 50 & 17.5 & 37 & 19.9 & 79 & 20.7 & \\
\hline$>6$ & 10 & 2.9 & 38 & 18.1 & 22 & 7.3 & & 25 & 8.7 & 17 & 9.1 & 52 & 13.6 & \\
\hline \multicolumn{15}{|l|}{ Prenatal care visits } \\
\hline 1st Trimester & & & & & & & $<0.001$ & & & & & & & \\
\hline No & 244 & 70.9 & 120 & 57.1 & 161 & 53.7 & & 45 & 15.7 & 29 & 15.6 & 51 & 13.4 & 0.021 \\
\hline$\leq 5$ & 100 & 29.1 & 90 & 42.9 & 138 & 46.0 & & 235 & 82.2 & 144 & 77.4 & 322 & 84.3 & \\
\hline$\geq 6$ & 0 & - & 0 & - & 1 & 0.3 & & 6 & 2.1 & 13 & 7.0 & 9 & 2.4 & \\
\hline 2nd Trimester & & & & & & & 0.029 & & & & & & & 0.830 \\
\hline No & 90 & 26.2 & 42 & 20.0 & 60 & 20.0 & & 62 & 21.7 & 39 & 21.0 & 75 & 19.6 & \\
\hline$\leq 5$ & 250 & 72.7 & 166 & 79.9 & 229 & 76.3 & & 220 & 76.9 & 144 & 77.4 & 304 & 79.6 & \\
\hline$\geq 6$ & 4 & 1.2 & 2 & 1.0 & 11 & 3.7 & & 4 & 1.4 & 3 & 1.6 & 3 & 0.8 & \\
\hline 3rd Trimester & & & & & & & 0.471 & & & & & & & 0.108 \\
\hline No & 86 & 25.0 & 47 & 22.4 & 57 & 19.0 & & 35 & 12.2 & 12 & 6.5 & 31 & 8.1 & \\
\hline$\leq 5$ & 233 & 67.7 & 149 & 71.0 & 219 & 73.0 & & 195 & 68.2 & 145 & 78.0 & 284 & 74.3 & \\
\hline$\geq 6$ & 25 & 7.3 & 14 & 6.7 & 24 & 8.0 & & 56 & 19.6 & 29 & 15.6 & 67 & 17.5 & \\
\hline $\begin{array}{l}\text { Tobacco use during } \\
\text { pregnancy }\end{array}$ & & & & & & & 0.376 & & & & & & & 0.075 \\
\hline Yes & 16 & 4.7 & 15 & 7.1 & 14 & 4.7 & & 10 & 3.5 & 12 & 6.5 & 10 & 2.6 & \\
\hline No & 328 & 95.3 & 195 & 92.9 & 286 & 95.3 & & 276 & 96.5 & 174 & 93.5 & 372 & 97.4 & \\
\hline \multicolumn{15}{|l|}{$\begin{array}{l}\text { Medical illness during } \\
\text { pregnancy }\end{array}$} \\
\hline Chronic hypertension & 70 & 20.3 & 23 & 11.0 & 43 & 14.3 & 0.009 & 28 & 9.8 & 13 & 7.0 & 40 & 10.5 & 0.404 \\
\hline Diabetes's mellitus & 14 & 4.1 & 10 & 4.8 & 11 & 3.7 & 0.828 & 15 & 5.2 & 9 & 4.8 & 31 & 8.1 & 0.197 \\
\hline Preeclampsia & 36 & 10.5 & 43 & 20.5 & 43 & 14.3 & 0.005 & 10 & 3.5 & 9 & 4.8 & 16 & 4.2 & 0.767 \\
\hline Haemoglobinopathy & 22 & 6.4 & 30 & 14.3 & 20 & 6.7 & 0.002 & 6 & 2.1 & 11 & 5.9 & 6 & 1.6 & 0.008 \\
\hline Antepartum haemorrhage & 23 & 6.7 & 24 & 11.4 & 37 & 12.3 & 0.038 & 11 & 3.8 & 8 & 4.3 & 11 & 2.9 & 0.642 \\
\hline $\begin{array}{l}\text { Premature rupture of } \\
\text { the membranes }\end{array}$ & 41 & 11.9 & 19 & 9.0 & 21 & 7.0 & 0.101 & 12 & 4.2 & 6 & 3.2 & 17 & 4.5 & 0.784 \\
\hline
\end{tabular}

Two sided $p$ values based on Pearson's chi square test \& fisher's exact test where the cell count was less than 5. 
Distribution of neonatal outcome among the cases and controls according to interpregnancy interval $(\mathrm{N}=1708)$.

\begin{tabular}{|c|c|c|c|c|c|c|c|c|c|c|c|c|c|c|}
\hline \multirow{3}{*}{ Variables } & \multicolumn{6}{|c|}{$\begin{array}{c}\text { Cases }(<2500 \mathrm{~g}) \\
\mathrm{N}=854\end{array}$} & \multicolumn{7}{|c|}{$\begin{array}{c}\text { Control }(\geq 2500 \mathrm{~g}) \\
\mathrm{N}=854\end{array}$} & \multirow{3}{*}{$p$} \\
\hline & \multicolumn{2}{|c|}{$\begin{array}{c}6-12 \\
\text { months } \\
(\mathrm{N}=344)\end{array}$} & \multicolumn{2}{|c|}{$\begin{array}{c}13-23 \\
\text { months } \\
(\mathrm{N}=210)\end{array}$} & \multicolumn{2}{|c|}{$\begin{array}{c}24-84 \\
\text { months } \\
(\mathrm{N}=300)\end{array}$} & \multirow[t]{2}{*}{$p$} & \multicolumn{2}{|c|}{$\begin{array}{c}6-12 \\
\text { months } \\
(\mathrm{N}=286)\end{array}$} & \multicolumn{2}{|c|}{$\begin{array}{c}13-23 \\
\text { months } \\
(\mathrm{N}=186)\end{array}$} & \multicolumn{2}{|c|}{$\begin{array}{c}24-84 \\
\text { months } \\
(\mathrm{N}=382)\end{array}$} & \\
\hline & $\mathrm{n}$ & $\%$ & $\mathrm{n}$ & $\%$ & $\mathrm{n}$ & $\%$ & & $\mathrm{n}$ & $\%$ & $n$ & $\%$ & $\mathrm{n}$ & $\%$ & \\
\hline \multicolumn{15}{|c|}{ Pregnancy outcome } \\
\hline Normal & 202 & 58.7 & 150 & 73.3 & 183 & 61.0 & & 226 & 79.0 & 132 & 71.0 & 285 & 74.6 & 0.213 \\
\hline Breech & 28 & 8.1 & 9 & 4.3 & 16 & 5.3 & 0.001 & 10 & 3.5 & 5 & 2.7 & 18 & 4.7 & \\
\hline Forceps & 21 & 3.5 & 10 & 4.8 & 12 & 4.0 & & 9 & 3.1 & 9 & 3.2 & 14 & 3.7 & \\
\hline Caesarian & 102 & 29.6 & 37 & 17.6 & 89 & 29.7 & & 41 & 14.3 & 13 & 23.3 & 65 & 17.0 & \\
\hline \multicolumn{15}{|l|}{ Labour } \\
\hline Spontaneous & 238 & 69.2 & 138 & 65.7 & 207 & 69.0 & 0.915 & 204 & 71.3 & 141 & 75.8 & 261 & 68.3 & 0.288 \\
\hline Induced & 44 & 12.8 & 29 & 13.8 & 40 & 13.3 & & 30 & 10.5 & 12 & 6.5 & 36 & 9.4 & \\
\hline Augmented & 62 & 18.0 & 43 & 20.5 & 53 & 17.7 & & 52 & 18.2 & 33 & 17.7 & 85 & 22.3 & \\
\hline \multicolumn{15}{|l|}{ Neonatal outcome } \\
\hline Singleton & 315 & 91.6 & 197 & 93.8 & 270 & 90.0 & & 283 & 99.0 & 179 & 96.2 & 372 & 97.4 & 0.145 \\
\hline Twins & 28 & 8.1 & 13 & 6.2 & 26 & 8.7 & 0.121 & 3 & 1.0 & 7 & 3.8 & 10 & 2.6 & \\
\hline$>3$ & 1 & 0.3 & 0 & - & 4 & 1.3 & & 0 & - & 0 & - & 0 & - & \\
\hline \multicolumn{15}{|l|}{ Baby status } \\
\hline Normal & 316 & 91.9 & 199 & 94.8 & 265 & 88.3 & & 267 & 93.4 & 176 & 94.6 & 363 & 95.0 & 0.640 \\
\hline $\begin{array}{l}\text { Dysmorphic/ } \\
\text { congenital } \\
\text { abnormalities }\end{array}$ & 28 & 8.1 & 11 & 5.2 & 35 & 11.7 & 0.036 & 19 & 6.6 & 10 & 5.4 & 19 & 5.0 & \\
\hline
\end{tabular}

Two sided $p$ values based on Pearson's chi square test \& fisher's exact test where the cell count was less than 5.

\section{Figure 1}

Relationship between interpregnancy interval and low birth weight.

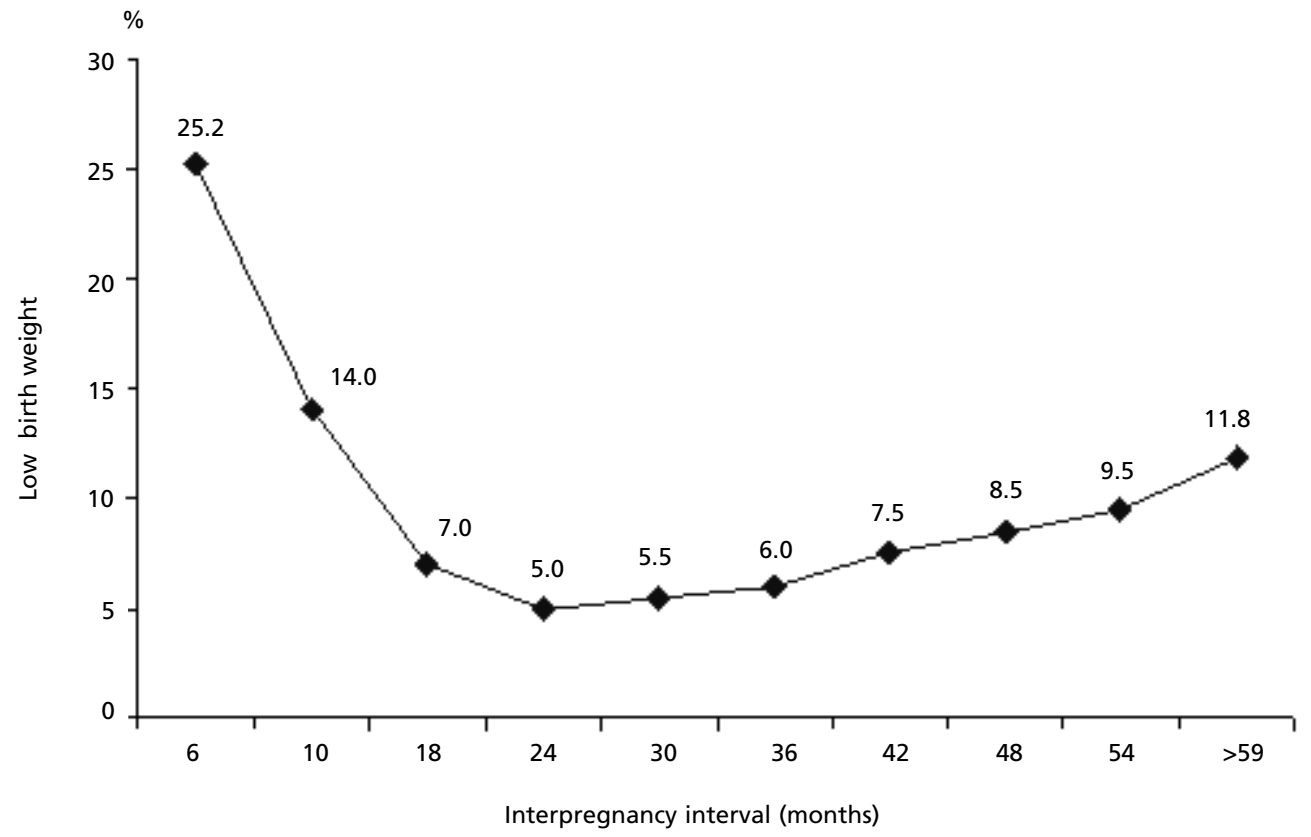




\section{Discussion}

A previous study by Bener et al. ${ }^{11}$ discovered that maternal complications affected both the mother and the risk of neonatal morbidity and mortality. A birth spacing program using contraceptives is not encouraged for Arab women and the interpregnancy interval has been reported as an important factor for the mother and child. Hence, the authors made an attempt to determine the impact of the interpregnancy interval on low birth weight and other adverse pregnancy outcomes in the State of Qatar. The study findings highlight the strong influence of interpregnancy interval on low birth weight. In the study sample of low birth weight newborns, the birth interval 6-12 months was higher among younger women below 25 years of age $(49.4 \%)$ than among the control group (21.7\%). A significant association was observed between birth interval and maternal age $(p<0.001)$ which is in line with another study 12 that found that birth interval increased with increasing maternal age. Increasing birth intervals with increasing maternal age is probably due to an increase in experience and knowledge of mothers with age or decreasing fertility. However, women need to be taught that long intervals are problematic when it causes the women to be over age 35 years at the time of pregnancy, since this is associated with adverse pregnancy outcomes. Conversely, in Canada, a study by Ram and Rahim 13 reported that there was no significant association between birth interval and marriage age.

Women whose educational level was lower than intermediate education $(41.2 \%)$ were more likely to deliver a low birth weight infant regardless of the birth interval. A short birth interval was observed to be more common among illiterate women (13.1\%) with low birth weight children compared to mothers of normal weight children (9.1\%). Generally, a short birth interval is influenced by the mother's educational status. It is a fact that, as education increases, the desire to limit the family size increases. Hajian et al. 14 have reported that a short birth interval is more common among women whose educational level is lower than high school education and a longer birth interval more common in women with a university education. These findings are similar to the educational status of the studied mothers of low birth weight infants with short and long interpregnancy interval. Short interpregnancy intervals were more common in women with a monthly household income of $<$ Qrs.5000/- (10.5\%) than in the control group $(6.6 \%)$. We observed no significant differences in women with high house hold income between the two groups.

Our socio-economic results for women with LBW newborns corroborate the statement of Ecob and Smith 15 that low socio-economic level is the most important risk factor for low birth weight, including income, education, occupation and household leadership in the family. These results show that women of a lower socio-economic level had a higher risk of LBW than those in the medium and high socioeconomic brackets. A Mexican study 16 found that low socioeconomic level was the most important risk factor for low birth weight. In Sweden, 17 the association between interpregnancy interval and pregnancy outcome is confounded by maternal socio-demographic status. These results describe a positive relationship between socioeconomic conditions and the effects on mothers' health, leading to low birth weight and other adverse birth outcome.

The present study suggests a positive association between birth interval and low birth weight. Nearly half of the women with high risk of LBW had a short interpregnancy interval of 6-12 months (40.3\%), whereas the majority of the mothers of normal weight children had a long birth interval of 2 years or more (44.7\%). In Ethiopia, 18 it has been reported that conceiving within 12 months of a previous delivery is a critical interval for causing LBW. The risk of LBW was higher in mothers with short $(40.3 \%)$ and long birth intervals $(35.1 \%)$. It was found that infants conceived 18-23 months after a live birth had the lowest risk of low birth weight in both the groups of low birth weight and normal weight children $(24.6 \% \& 21.8 \%)$. The results of the present study corroborate the findings of earlier studies that women with short and long birth intervals are at increased risk of low birth weight. 19,20 A possible explanation for the relationship between short birth interval and LBW is the maternal nutritional depletion hypothesis, which states that a close succession of pregnancies and period of lactation worsen the mother's nutritional status and there is no adequate time for the mother to recover from the physiological stresses of the preceding pregnancy before she is subjected to the stresses of the next. Two recent studies conducted in $\mathrm{Utah}^{20}$ and Michigan ${ }^{21}$ have revealed an apparent optimal interpregnancy interval of 18-23 months, which is associated with the lowest risk of adverse pregnancy outcomes, including low birth weight, preterm delivery, short gestational age and so forth. Our study findings regarding the association of birth interval and LBW are almost universally found and similar findings have been reported by many studies. $19-22$ 
The present study demonstrated a J-shaped association between interpregnancy interval and LBW. The risk for low birth weight was highest when the birth interval was the lowest, below 6 months $(25.2 \%)$, and then the risk declined rapidly as the birth interval increased and was lowest for women with a birth interval of 23 months. Evidence has consistently shown that a birth interval of 2 years improves the chances of infant and child survival22 Again the risk increased linearly for women with an interpregnancy interval longer than 24 months. The J-shaped association between birth interval and LBW has been observed in many studies. 22,23

The interpregnancy interval has been associated with maternal characteristics and adverse pregnancy outcomes. 24 The present study also revealed that a short interpregnancy interval is linked to antenatal care visits, underweight and pregnancy complications. In the present study, mothers of LBW babies with a short birth interval (6-12 months) were more likely to be underweight $(8.1 \%)$ than mothers of normal weight children (4.5\%). The Annual Health report 10 of the Hamad Medical Corporation has revealed a proportion of 7 to $8 \%$ of LBW among newborns during the last five years, which is in line with the results of this study, especially in mothers with a short birth interval (8.1\%). A study conducted by Ehrenberg et al. 25 has reported that low maternal weight before pregnancy is associated with high risk of LBW.

A study by Haijan et al. 14 has reported that birth interval decreases significantly with increasing parity. But, in the present study, there are no obvious differences found in the interpregnancy interval groups with regard to parity. Chronic hypertension was a significant pregnancy complication in the women studied who had low birth weight children, especially in mothers with short birth intervals (20.3\%). Compared to the control group, pregnancy illness was higher in women with low birth weight children. Women with LBW children and a short birth interval tended not to have attended antenatal clinics $(70.9 \%)$ during the 1 st trimester. Lack of antenatal care is significantly associated with low birth weight. 26 A lower number of antenatal visits during the $1^{\text {st }}$ trimester was common in mothers studied who had low birth weight children, whereas adequate prenatal care was observed in mothers of normal weight children. Normal delivery was lower in women with a LBW child and a short birth interval (58.7\%) than in the control group (79\%). Likewise, multiple births occurred more among mothers of LBW children, especially those with a long birth interval of more than 2 years $(10 \%)$, whereas multiple births were less common among mothers of normal weight children. These findings indicate that both short and long birth intervals are independently associated with a significant increase in the risk of LBW and other adverse pregnancy outcomes, which is consistent with another study by Sachar et al. 27

The study findings suggest that spacing pregnancies appropriately could reduce the rate of low birth weight and adverse pregnancy outcomes. It is worth noting that the optimal interval associated with the lowest risk of adverse birth outcome was 13-24 months. Hence, our study advises women on the benefits of delaying a subsequent pregnancy for approximately 2 to 4 years to improve the health of both mother and the next infant. A short interpregnancy interval is considered to be a potentially modifiable risk factor for low birth weight. There should be a health awareness program on the association between adverse pregnancy outcomes and short and long birth intervals and on the benefits of optimizing the birth interval.

\section{Final considerations}

The present study indicates that the length of the interval between pregnancies has a substantial effect on the risk of low birth weight and other adverse pregnancy outcomes. The main finding was that very short and prolonged interpregnancy intervals are related to an increased risk of low birth weight. The results reveal that the risk of low birth weight was higher in younger mothers with a short interpregnancy interval compared to mothers of normal weight children. Consistent with other studies, the study demonstrated a J-shaped association between interpregnancy interval and low birth weight. The birth interval of the women studied was influenced by their socio-economic status, including factors such as age, education and monthly household income.

\section{Acknowledgements}

The project was supported and funded by the Qatar Foundation Grant No.UREP-08-046-3-010. We also, would like to thank Hamad Medical Corporation for their approval this study (HMC Research Protocol \#10145/10). 


\section{References}

1. Kazaura MR, Kidnato ML, Massawe SN. Levels, trends and risk for early neonatal mortality at Muhimbili National Hospital, Tanzania, 1999-2005. East Afr J Public Health. 2006; 3: 10-3.

2. WHO (World Heatlh Organization). Perinatal mortality: a listing of available information. Geneva, Switzerland: World Health Organization, Family and Reproductive health; 1996. p. 8-15.

3. Miller JE, Birth intervals and perinatal health an investigation of three hypothesis, Fam Plann Perspect. 1991; 23; 6270 .

4. King JC. The risk of maternal nutritional depletion and poor outcome increases in early or closely spaced pregnancies. J Nutr. 2003; 133: 1732S-6S

5. Klebanoff MA. The Interval between pregnancies and the outcome of subsequent births. N Engl J Med. 1999; 340: 643-4.

6. UNICEF, WHO (United Nations Children's Fund and World Health Organization). Low birth weight: country, regional and global estimates. New York: UNICEF; 2004.

7. James AT, Bracken MB, Cohen AP, Saftlas A, Lieberman E. Interpregnancy interval and disparity in term small for gestational age births between black and white women. Obstet Gynecol. 1999; 93: 109-12.

8. Shults RA, Arndt V, Olshan AF, Martin CF, Rpyce RA. Effects of short interpregnancy interval on small-for-gestational age and preterm births. Epidemiol. 1999; 10: 250-4.

9. Khoshnood B, Lee KS, Wall S, Hsieh HL, Mittendorf R Short interpregnancy intervals and the risk for adverse birth outcomes among five racial/ethnic groups in the US. Am J Epidemiol. 1998; 148: 778-805.

10. Annual Health Report for the year 2009. Department of Medical Statistics and Epidemiology. Hamad Medical Corporation; 2010.

11. Bener A, Al-Nufal M, Vachhani PJ, Ali AI, Samson N, Saleh MN. Maternal complications with neonatal outcome among Arab women in a fast developing country. J Fam Commun Med. 2012 (in the press).

12. Mo Al-Nahedh NNA. The effect of socio-demographic variables on child-spacing in rural Saudi Arabia. East Mediterr Health J. 1999; 5: 136-40.

13. Ram B, Rahim A. Emerging pattern of child spacing in Canada. J Biosoc Sci. 1994; 26: 155-67.

14. Hajian KO, Ansafi N, Aliakbarnia-Omrani F. The patterns and determinants of birth intervals in multiparous women in Babol, Northern Iran, Southeast Asian. J Trop Med Public Health. 2009; 40: 852-60.
15. Ecob R, Smith GD. Income and health: what is the nature of the relationship? Soc Sci Med. 1999; 48: 693-705.

16. Torres-Arrcola LP, Constantino-Casas P, Flores-Hernandez S, Villa-Barragan JP, Rendon-Macias E. Socioeconomic factors and low birth weight in Mexico. BMC Public Health. 2005; 5: 20.

17. Stephansson O, Dickman PW, Cnattingius S. The influence of interpregnancy interval on the subsequent risk of Still Birth and early neonatal death. Obst Gynecol. 2003; 102: 101-8.

18. Getachew K. Impact of spacing on outcome of pregnancy in Tikur Antessa and St. Paul's hospital, presented to AAU Medical Faculty department of OBS \& GYN in the partial fulfilment of certification in obstetrics and gynecology. December 1998.

19. Smith GC, Pell JP, Dobbie R. Interpregnancy interval and risk of preterm birth and neonatal death: retrospective cohort study. BMJ. 2003; 327: 313-6.

20. Zhu BP, Rolfi RT, Nangle BE, Horan JM. Effect of the interval between pregnancies on perinatal outcomes. $\mathrm{N}$ Engl J Med. 1999; 340: 589-94.

21. Zhu BP, Le T. Effect of interpregnancy interval on infant low birth weight: a retrospective cohort study using the Michigan Maternally linked Birth database. Matern Child Health J. 2003; 7: 169-78.

22. Boerma J, Bicego G. Preceding birth interval and child survival. Stud Fam Plann. 1992; 23: 243-56.

23. Augustin CA, Jose B, Maureen N, Anyeli RB. Effect of interpregnancy interval on perinatal outcomes in Latin America. Obstet Gynecol. 2005; 106: 359-66.

24. Fuentes Afflick E, Hessol NA. Interpregnancy interval and the risk of premature infants, Obstet Gynecol. 2000; 95: 383-90.

25. Ehrenberg HM, Dierker L, Milluzi C, Mercer BM. Low maternal weight, failure to thrive in pregnancy and adverse pregnancy outcomes. Am J Obstet Gynecol. 2003; 289: 1726-30.

26. Adam I, Ismail MH, Nasr AM, Prins MH, Smits LJM. Low birth weight, preterm birth, and short interprepgnancy interval in Sudan. J Matern Fetal Neonatal Med. 2009; 22: 1068-71.

27. Sachar RK, Soni RK. Perinatal mortality in rural Panjab: a population based study. J Trop Pediatr. 2000; 46: 43-5. 